Article Type: Research Paper

\title{
Creative-Innovative Role and Human Capital: An Interrelationship Analysis
}

\author{
Sari Lestari Zainal Ridho* and Neneng Miskiyah
}

\section{AFFILIATION:}

Department of Business Administration, Sriwijaya State Polytechnic. Palembang. Indonesia.

\section{*CORRESPONDENCE:}

sarilestari@polsri.ac.id

THIS ARTICLE IS AVALILABLE IN:

http://journal.umy.ac.id/index.php/mb

DOI: $10.18196 / \mathrm{mb} .11187$

\section{CITATION:}

Ridho, S. L. Z., \& Miskiyah, N. (2020). Creative-Innovative Role and Human Capital: An Interrelationship Analysis. Jurnal Manajemen Bisnis, 11(1), 57-64.

Received: 13 November 2019

Accepted: 1 February 2020

\begin{abstract}
Improving performance as an effort to deal with change is a necessity, so the use of digital marketing to improve organizational performance in developing the tourism industry in Indonesia in the industrial era 4.0, applied to the Indonesian Ministry of Tourism, one of which is in the implementation of the Indonesian Enchantment Generation. The purpose of this study is to clarify the impact of human, social and intellectual capital from the use of digital marketing on the creative and improvise role of the Indonesian Enchantment Generation members. This research uses a survey approach. The study population was members of the tourism community, the Ministry of Tourism in Indonesia, selected as a sample in this study. Hypothetically, it is believed that human, social and organizational capital has a linear and positive relationship to the creative and innovative roles of community members, and this study will present the results of data processing of relationships between these variables, which are processed using regression techniques. Based on the results of the study, it can be concluded that human capital and intellectual capital have a positive and significant influence on the creative and innovative role of the Indonesian Enchantment Generation community members in Indonesia.
\end{abstract}

Keywords: Human Capital; Social Capital; Intellectual Capital.

\section{Introduction}

Facing the global market, increasing the nation's competitiveness in all fields including the economic sector is a necessity that must be done. Tourism in Indonesia is one of the mainstay sectors that is believed to have a positive impact on the economy which also faces competition with other tourist destination countries.

At the Third National Tourism Coordination Meeting in 2018, tourism was determined as the mainstay sector in generating foreign exchange, during the January-July 2018 period; the tourism sector had contributed foreign exchange of USD 9 million, and in July 2018 had contributed foreign exchange of USD 1.5 million. Furthermore, in the coordination meeting, it was stated that the government is targeting foreign exchange of USD 20 billion, with the target of visiting 20 million foreign tourists and 275 million domestic tourist in 2019 (Febrinastri, 2018). 
Based on the foregoing thoughts, an increase in the number of tourist visits to Indonesia is needed. One of the strategies undertaken by the Ministry of tourism in increasing tourist arrivals is to empower existing human resources as capital (human capital) that can adapt to technology, by forming a tourism community consisting of millennials called Generasi Pesona Indonesia (GenPI) ).

GenPI is a community that likes tourism, which has the main activity which is to promote regional tourism potential, its activities are carried out both online and offline. Online, this community uses online (social) media as a means of promotion (digital marketing), such as Instagram, Twitter, Facebook and other social media with tourism content. While offline, GenPI implements events or participates in various regional and national tourism events.

The use of online media in marketing tourism products and or services (digital marketing) by GenPi members is an innovation in adapting technology to help human resource organizations in improving performance because of the development of paradigm changes related to human resources which were initially only considered as part from administrative functions, but is now believed to play an important role in improving organizational performance. This has become one of the rationale in considering doing this research.

\section{Literature Review and Hypotheses Development}

Theoretically, using role theory (Solomon, Surprenant, Czepiel, \& Gutman, 1985), organizational performance is measured by indicators of the role that the organization runs. Based on role theory, organizational performance as measured by role indicators, has several roles, one of which is the role of differentiator (Role Discrepancy) which is focused on the elements Creativity and innovation (improvisation) of organizational resources as an effort to overcome differences in perception between members of the organization and users of services / products of the organization, then in this study will be used the term creative and innovative roles for the mention of role discrepancy.

Empirically, previous research proves the link between human capital and organizational performance (Marimuthu, Arokiasamy \& Ismail, 2009; Liesander, Indra \& Dharmayanti, Diah, 2017), evaluating the impact of human capital on company performance, and finding that there is a positive influence on capital human performance of the company. Goodarzi (2016) examined the relationship between human capital development and innovation in health organizations, the results of the study stated that innovation influences the increase in the efficiency of human capital (employees).

Based on phenomena, theoretical approaches, and previous research, the problem in this study is whether there is an influence of human capital along with other variables, social capital and organizational capital on the creative and innovative role of the tourism community represented by the Indonesian Enchantment Generation (GenPI). Based on the formulation of the problem, this study aims to clarify the interrelationship (impact) or 
examine the influence (effect) of human capital, and social capital and organizational capital, on the creative and innovative role (role discrepancy) of Community members, The Indonesian Generation of Enchantment, as a result of the use of technology (digital marketing) in promoting tourism products in Indonesia, is considered important, by reason of distinguishing it from previous research and establishing relevance to the current conditions that demand organizational adaptation to technology. In order to achieve the purpose of this research, the hypotheses in this study are:

\section{$\boldsymbol{H}_{1}$ : Pertially, there is an effect of human capital on creative-innovative role \\ $H_{2}$ : Partially, there is an effect of social capital on creative-innovative role \\ $H_{3}$ : Partially, there is an effect of intellectual capital on creative-innovative role}

\section{Research Method}

The population in this study is a member of the tourism community, the Indonesian Enchantment Generation in Indonesia totaling 2000 people based on data in February 2018 (Jackysan, 2018, source: official website of the Indonesian Enchantment Generation, Lombok chapter, 2019). While the sample taken uses a purposive sampling technique, which is a sampling technique where the researcher determines the sampling by specifying specific characteristics that are appropriate to the purpose of the study so that it is expected to be used as a sample in research that can answer the research problem.

The variables that will be used in this study are 4 variables, human capital, and social capital, organizational capital and creative and innovative roles with operational definitions as follows:

a. Human Capital, Human Capital, is wealth in the form of knowledge, experience, and skills of human resource organizations (Becker, 1993; Marimuthu, Arokiasamy \& Ismail, 2009). Human capital can also be defined as the sum of the abilities, skills, attitudes, commitments, experience and educational background of the workforce that enables them to act in ways that are of economic value to individuals and organizations (Shih, Chang \& Lin, 2010)

b. Social Capital, Social Capital, refers to the ties and relationships between members of a network as valuable resources through the creation of norms and mutual trust that will prepare the basis for achieving all the goals desired by members of each organization (Salajegheh \& Pirmoradi, 2013). Social capital is an organizational asset that makes social networks the core (Sato, 2013).

c. Organizational Capital, Organizational Capital, is defined as institutionalized knowledge and codified experience stored in organizational images, culture, routines, procedures, information systems, and patents, and is a strategic organizational intangible asset (Gilbert, Ah, \& Broome, 2017). 
d. Innovative Creative Role, Role Discrepancy, is a role to succeed in overcoming problems that arise as a result of differences caused by the inconsistency between the perception of organizational human resources (labor) regarding a task or job qualifications and expectations or expectations of consumers, as an illustration of the form this role is in terms of the workforce communication function in the form of creative service sales (Solomon, et al., 1985).

Analysis of the data used in this study is a statistical analysis of multiple linear regression tests, which previously performed several tests first, namely the validity test and the reliability test of respondents' answers to the questions asked. This research uses a multiple linear regression model using the Robust $\mathrm{M}$-Estimator regression parameter estimator.

In the regression method, Ordinary Least Square (OLS) estimation results in a biased estimate when the distribution assumptions are not met. Regression method used when the distribution of residuals is not normal or several outliers influence the model, namely Robust Regression (Chen, 2002; Draper and Smith, 1998).

When researchers formulate a regression model and test the assumptions it is found that the regression assumptions are violated, the transformation carried out will not eliminate or weaken the influence of the outliers that ultimately predictions or estimation results (regression coefficients) become biased. In this situation, robust regression that is resistant to the influence of outliers is the best method. Robust regression is used to detect outliers and give results that are resistant to outliers (Chen, 2002). The following are described in the regression model to be estimated:

$$
z=b_{0}+b_{1} y_{1}+b_{2} y_{2}+b_{3} y_{3}+e_{1}
$$

Explanation of information about the research variables and their values is given in the following table 1.

Table 1 Characteristics of each research variable used in the simultaneous model.

\begin{tabular}{lclll}
\hline Variable & Symbol & Meaning & Value & Scale \\
\hline Dependent & $z$ & $\begin{array}{l}\text { Creative Innovative Role } \\
\text { (Role Discrepancy) }\end{array}$ & $z>0$ & Interval \\
Independent & $y_{1}$ & Human Capital & $y_{1}>0$ & Interval \\
& $y_{2}$ & Social Capital & $y_{2}>0$ & Interval \\
& $y_{3}$ & Organizational Capital & $y_{3}>0$ & Interval \\
\hline
\end{tabular}

Source: processed for research purposes, 2019

In robust regression, the estimation method used is the M-estimation method. The goodness of the model is assessed by the value of R-Square, R-Square adjusted, and Standard Deviation. Next to test the regression coefficients of equations $\mathrm{y}_{1}$ and $\mathrm{y}_{2}$ with the t-test given with the following hypothesis:

$H_{0}$ : There is no partial effect of $y_{1}, y_{2}$, and $y_{3}$ on $z$.

$H_{1}$ : There is an effect partiall $y_{1}, y_{2}$, and $y_{3}$ on $z$. 
Table 2 List of Variables

\begin{tabular}{|c|c|c|}
\hline Variable Name & Symbol & Measuring Instrument (Description) \\
\hline \multirow[t]{2}{*}{ Human Capital } & \multirow[t]{2}{*}{$\mathrm{y}_{1}$} & $\begin{array}{l}\text { Digital Marketing makes it easy for members of the tourism } \\
\text { community to learn tourism products/services }\end{array}$ \\
\hline & & $\begin{array}{l}\text { Digital marketing makes it easy for members of the tourism } \\
\text { community to provide information services to tourists }\end{array}$ \\
\hline \multirow[t]{2}{*}{ Social Capital } & \multirow[t]{2}{*}{$\mathrm{y}_{2}$} & $\begin{array}{l}\text { Digital Marketing keeps members of the tourism community } \\
\text { close to tourists }\end{array}$ \\
\hline & & $\begin{array}{l}\text { Digital marketing makes it easy for members of the tourism } \\
\text { community to communicate with related parties/stakeholders } \\
\text { (community, government, private) }\end{array}$ \\
\hline \multirow[t]{2}{*}{$\begin{array}{l}\text { Intellectual } \\
\text { Capital }\end{array}$} & \multirow[t]{2}{*}{$\mathrm{y}_{3}$} & $\begin{array}{l}\text { Digital Marketing makes it easy for members of the tourism } \\
\text { community to find information }\end{array}$ \\
\hline & & $\begin{array}{l}\text { Digital marketing makes it easy for members of the tourism } \\
\text { community to understand the routine process of the organization } \\
\text { (community) / learn the standard procedures for implementing } \\
\text { organizational activities }\end{array}$ \\
\hline \multirow{2}{*}{$\begin{array}{l}\text { Creative- } \\
\text { Innovative Role } \\
\text { (Role } \\
\text { Discrepancy) }\end{array}$} & \multirow[t]{2}{*}{ Z } & $\begin{array}{l}\text { Digital Marketing enhances the creativity of members of the } \\
\text { tourism community }\end{array}$ \\
\hline & & $\begin{array}{l}\text { Digital marketing helps members of the tourism community } \\
\text { innovate }\end{array}$ \\
\hline
\end{tabular}

Source: processed for research purposes, 2019.

In the partial/individual test of the coefficient of the model with the t-test, a significant effect is given when the P-value $\leq \alpha$ with $\alpha$ is determined at $10 \%, 5 \%$, or $1 \%$. The variables used in this study are described in Table 2 . The table shows the names of the variables used in the study, symbols that represent variables and measuring devices used to measure these variables.

\section{Result and Discussion}

This section will explain and discuss the results and implications of this study, beginning with the presentation of the results and then discussing these results in the form of discussion including the implications of these results. The results of this study as shown in Table 3, from the output of equation $z$, the test results are as follows:

1. Variable $y_{1}$ to $z$ with a regression coefficient of 0.265982 (positive influence) and Pvalue (Prob.) Of 0.0002 so that testing can be concluded that there is a significant influence of $y_{1}$, human capital on $z$, Innovative Creative Role.

2. Variable $y_{2}$ to $z$ with a regression coefficient value of 0.076784 (near zero) and P-value (Prob.) Of 0.2503 so that testing can be concluded that there is no significant effect of y2, Social Capital on z, Innovative Creative Role.

3. Variable $y_{3}$ to $z$ with a regression coefficient of 0.490701 (positive influence) and Pvalue (Prob.) of 0.0000 so that the test can be concluded that

There is a significant influence $y_{3}$, Organizational Capital on z, Innovative Creative Role. 
Ridho \& Miskiyah

Creative-Innovative Role and Human Capital: An Interrelationship Analysis

Table 3 T-test results for the significance of the coefficient of equation $z$.

\begin{tabular}{llcccl}
\hline $\begin{array}{c}\text { Variable } \\
\text { Dependent }\end{array}$ & \multicolumn{1}{c}{$\begin{array}{c}\text { Variable } \\
\text { Independent }\end{array}$} & $\begin{array}{c}\text { Regression } \\
\text { coefficient }\end{array}$ & $\begin{array}{c}\text { Standard } \\
\text { Error }\end{array}$ & $\begin{array}{c}\text { Statistic } \\
z\end{array}$ & \multicolumn{1}{c}{ P-value } \\
\hline $\mathrm{z}$ & Constants & 0,732427 & 0,308053 & 2,377605 & $0,0174^{* *}$ \\
& $\mathrm{y}_{1}$ & 0,265982 & 0,072103 & 3,688907 & $0,0002^{* * *}$ \\
& $\mathrm{y}_{2}$ & 0,076784 & 0,066793 & 1,149593 & 0,2503 \\
& $\mathrm{y}_{3}$ & 0,490701 & 0,066207 & 7,411669 & $0,0000^{* * *}$ \\
\hline
\end{tabular}

Source: research data processing results, 2019

* Significant for a significant level $(\alpha)$ of $10 \%$.

** Significant for a significant level $(\alpha)$ of $5 \%$.

$* * *$ Significant for a significant level $(\alpha)$ of $1 \%$.

By applying M-Estimation the robust regression model is obtained as follows:

$$
=0.732427+0.265982 y_{1}+0.076784 y_{2}+0.490701 y_{3}(2)
$$

For the validation process, Goodness-od-fit measures are used, namely the coefficient of determination $\left(R^{2}\right)$ and Mean Square Error (MSE). The coefficient of determination ( $R-$ Square) is defined as the diversity of endogenous variables that can be explained simultaneously by exogenous variables of R-Square where the remainder is explained by errors or other variables not included in the simultaneous equation. In other words, the goodness of the simultaneous equations formed is indicated by the value of R-Square. The greater the value of R-Square, the better the simultaneous equation formed. In this study the value of R-Square is 0.413032 (Prob (Rn-square stat. 00000), which shows the diversity of endogenous variables that can be explained simultaneously by exogenous variables by $41 \%$, the rest is explained by errors or other variables not included in the in the simultaneous equation From the results of the validation of the research equation model, a goodness-of-fit measure, namely R-Square and MSE, a good enough value for the regression model with estimated $\mathrm{M}$ well.

The main objective in this research, as mentioned at the beginning is to interpret the influence of human capital, social capital and organizational capital on organizational performance in the form of creative and innovative roles as a result of the use of technology, digital marketing, in organizational activities. Based on the test results, this study found that human capital and organizational capital has a significant influence on the creative and innovative role of members of the tourism community, Generasi Pesona Indonesia. Therefore to create a creative and innovative role, it must focus on human capital and organizational capital.

Furthermore, the test results also found that there was no impact on the use of digital marketing on social capital on creative and innovative roles. This is supported by the findings of previous studies that found social media users empirically have a social life that is only slightly wider than non-users of social media and communication through online media mostly only with those they know (Uslaner, 2004).

It has also been found empirically in research that using internet technology to communicate and build closeness and social connections will succeed if combined with 
face-to-face communication (Håkansson \& Witmer, 2015), this shows that the use of digital technology or digitalization cannot replace overall social interaction in the form of face to face. In other words, although it cannot be denied the role of technology helps but does not have a role to replace as a whole.

The findings in this study are expected to contribute to developments both theoretically and practically in the field of human resources and performance. The results of this study theoretically build new concepts regarding the linkages of human capital, social capital and organizational capital to organizational performance as a result of the use of technology in the form of internet / online media (digital marketing), that the use of social media in social organization capital does not have an impact on the formation of creative roles and innovative, which is caused by the conditions needed to establish communication, closeness, and social connections.

Furthermore, the implications in this study are first, the need to focus on developing human capital and organizational capital in the realization of increasing creative and innovative roles, both of which have a positive influence on these creative and innovative roles. Second, the need for an increase in communication activities, online communication is enhanced by expanding to strangers, as well as offline, that is, communicating more face-to-face to bring members of the Indonesian Charm Generation closer and communicating with related parties, the public (including tourists), government and private.

\section{Conclusion}

The tourism community is one of the organizations that play a role in supporting tourism activities in Indonesia, where the use of information technology is one of the keys to success in achieving goals. This study aims to evaluate the use of digital marketing concerning examining the relationship between human capital, social capital, and organizational capital as well as organizational performance in the form of creative and innovative roles among members of the Indonesian Enchantment Generation. The results of this research find that there is a positive and significant influence of human capital and organizational capital on the creative and innovative roles of community members, in accordance with the research allegations, while social capital has no influence, although this is different from the alleged research, these findings can be explained by Assumptions in the use of the internet as a means of building social capital.

This study also has several limitations, namely studies conducted only on human, social and organizational capital on one of the roles assumed by the organization. This study also only uses data in a certain period, which is possible to give different results if the data is collected in the long term. So it can be a recommendation for future research to add to the organization's role variable as a measure of performance, and also consider using longer data collection methods. 


\section{References}

Becker, G. S. (1993). Human Capital: A Theoretical and Empirical Analysis with Special Reference to Education ( $3 r d$ ed), University of Chicago Press, Chicago.

Chen, C. (2002). Robust Regression and Outlier Detection with the Robustreg Procedure, Paper 265-267, SAS Institute: Cary, NC.

Febrinastri, F. (2018). Menpar: Tourism Is the Mainstay of Foreign Exchange Generating Sector, Votes, Obtained from URL

https://www.suara.com/bisnis/2018/09/27/150000/menpar-pisata-isisata foreign exchange-earners

Gilbert, J. H., D., Ah., D. V., \& Broome, M. E. (2001). Organizational Intellectual Capital and the role of the nurse manager: A proposed conceptual model. Nurs Outlook. 65(6): 679-710. https://doi.org/10.1016/j.outlook.2017.04.005

Goodarzi, M.R., Goodarzi, A. \& Goodarzi, E. (2016). The Role of Human Capital Development and Innovation in Health care Organizations of Markazi Province in Iran. Journal of Health Management \& Informatics, 3(1): 20-25. https://doi.org/10.1109/uksim.2010.14

Håkansson, P. \& H. Witmer. (2015). Social Media and Trust-A Systematic Literature review. Journal of Business and Economics, 6 (3): 517-524. https://doi.org/10.15341/jbe(21557950)/03.06.2015/010

Jackysan, (2018, February 3), Genpi, Generation of Indonesian Enchantment, Lombok, Indonesia, Retrieved from https://www.genpilomboksumbawa.com/3559/genpigenerasi-pesona-indonesia.html.

Liesander, I., \& Dharmayanti, D. (2017). Pengaruh Digital Marketing Terhadap Organizational Performance dengan Intellectual Capital dan Perceived Quality Sebagai Variabel Intervening Pada Industri Hotel Bintang Lima Di Jawa Timur. Jurnal Strategi Pemasaran, 4 (2): 1-13. Recieved from http://publication.petra.ac.id/index.php/manajemenpemasaran/article/view/5690/5190

Marimuthu, M., Arokiasamy, L. \& Ismail, M. (2009). Human Capital Development and Its Impact on Firm Performance: Evidence from Development Economics. The Journal of International Social Research, 2(8), 265-272.

https://www.researchgate.net/publication/26628217_Human_Capital_Development and Its Impact on Firm Performance Evidence from Developmental Economi $\underline{\mathrm{CS}}$

Draper, N. R. \& Smith, H. (1998). Applied Regression Analysis, USA: John Wiley \& Sons Inc.

Salajegheh, S. \& Pirmoradi, N. (2013). Social Capital of the Organization. International Journal of Engineering Research and Development, 7(12): 40-52. Received from http://www.ijerd.com/paper/vol7-issue12/F07124052.pdf

Sato, Y. (2013). Social Capital, Sociopedia.isa, 1-10.

Shih, K, Chia-Jung, C., \& Lin, B. (2010). Assessing knowledge creation and intellectual capital in the banking industry. Journal of Intellectual Capital, 11(1), 74-89. received from https://www.researchgate.net/publication/235281323 Assessing knowledge creatio $\underline{\mathrm{n}}$ and intellectual capital in banking industry

Solomon, M.R., Surprenant, C., Czepiel, J.A. \& Gutman, E.G. (1985). A Role Theory Perspective on Dyadic Interactions: The Service Encounter. Joumal of Marketing, 49 (Winter 1985), 99-11. Received from https://www.ida.liu.se/ steho87/und/htdd01/5002883.pdf

Uslaner, E. M. (2004). Trust, Civic Engagement, and the Internet. Political Communication, 21(2): 223-242. https://doi.org/10.1080/10584600490443895 